\title{
Reconfigurations of Business Environment in Tourism Industry Under the Impact of COVID-19
}

\author{
Gina Ionela Butnaru ${ }^{1}$, Maria Magdalena Maftei $^{2}$ and Mirela Ștefănică ${ }^{1}$ \\ 1) Alexandru Ioan Cuza University, Iaşi, Romania. \\ ${ }^{2}$ Ștefan cel Mare University, Suceava, Romania. \\ E-mail: gina.butnaru@uaic.ro; E-mail: mariamagdalenamaftei@gmail.com; \\ E-mail: mirela.stefanica@uaic.ro
}

\begin{abstract}
Please cite this paper as:
Butnaru, G.I., Maftei, M.M. and Ștefănică, M., 2021. Reconfigurations of Business Environment in Tourism Industry Under the Impact of COVID-19. In: R. Pamfilie,V. Dinu, L. Tăchiciu, D. Pleșea, C. Vasiliu eds. 2021.7th BASIQ International Conference on New Trends in Sustainable Business and Consumption. Foggia, Italy, 3-5 June 2021. Bucharest: ASE, pp. 326-335 DOI : $10.24818 /$ BASIQ/2021/07/042
\end{abstract}

\begin{abstract}
The main purpose of this paper is to analyse the reconfiguration of the business environment in the tourism industry as a result of the effects of the COVID-19 pandemic. The COVID-19 pandemic, perceived as the deepest crisis in the history of tourism, strongly influenced people's lives and their leisure behaviour, and led to the cessation of global business in general, and of tourism in particular. The widespread pandemic raised significant challenges for the development and sustainability of tourism, agrotourism, and business in areas with tourism potential. Thus, we highlighted the fact that a sustainable recovery aiming economic prosperity, environmental integrity, and social equity can be achieved only in a context where the entire planet is aware of the globalisation and of the importance of education in managing cooperation between peoples. This research focuses on an analysis of the business of tourism industry under the effect of the COVID-19 pandemic, as well as how these businesses will have to adapt in order to survive in the new conditions. In this context, COVID-19 becomes an accelerator for cooperation and digitalisation, and leadership is fundamental and vital to bring together business representatives, academics, and all citizens with a global perspective, who can put into motion capital flows, investments, technology, people, and ideas. The results of this research underline the fact that all tourism activities will have to be reconfigured to survive, and policy makers will have to come up with initiatives and focus on supporting and developing the operations of tourism companies during the COVID-19 pandemic.
\end{abstract}

\section{Keywords}

business environment, tourism industry, Covid-19 crisis, global/European perspective.

DOI: $10.24818 / B A S I Q / 2021 / 07 / 042$

\section{Introduction}

The new type of coronavirus, abbreviated COVID-19 (SARS-CoV-2), affected the business environment of the tourism industry, and millions of people missed the chance to explore new destinations, to embrace different cultures and customs, missing opportunities to create new jobs, to support businesses initiated for the development and protection of tourist destinations. The COVID-19 pandemic has been affecting human health and global economies (Donthu and Gustafsson, 2020), due to the fact that the SARS-CoV-2 virus is highly contagious (Liu, et al., 2020, Hafner, 2020). International tourist arrivals in the first quarter of 2020 dropped to a fraction of what they were a year ago (UNWTO, 2020). The tourism sector has been one of the most affected sectors of activity due to the closure of airports, the suspension of activities in the hotel industry, travel restrictions, etc (The Guardian, 2020). Thus, companies in the service sector in general, and tourism in particular were severely affected by the inherent risk regarding people's safety and health. The COVID-19 crisis 
significantly affected the business environment in the tourism industry, as some of them either completely suspended their operations, or reduced them considerably for a limited period of time (European Parliament, 2020), or adapted to the new situation, thus developing the online trade in response to the fact that people were isolated at home (Dannenberg, et al., 2020). According to the UNWTO (2020), the perspectives fell sharply and showed a high degree of uncertainty about the near future for the tourism sector. However, confronted with such a recession, tourism ended the year 2020 more united and determined than ever (Pololikashvili, 2020). Thus, according to Gössling, et al. (2020), tourism is an industry in which incomes are permanently lost because unsold products and services (such as accommodation) cannot be sold at a later date. Although accommodation can usually be sold online, it requires physical contact (the tourist must physically live in the accommodation unit). In this context, economic operators engaged in tourism-related activities recorded significant decreases in revenue (Do, et al., 2021) due to lower demand, increased cancellations or postponements of the services already contracted (UNWTO, 2020).

\section{Research methodology}

The aim of the research is to analyze the reconfiguration of the business environment in the tourism industry as a result of the effects of the COVID-19 pandemic.

The objectives of the research are:

- $\quad$ analysis of the tourism sector in the current pandemic context

- $\quad$ identifying the effects of the health crisis on the tourism industry, respectively the business environment in the tourism industry

- $\quad$ highlighting the necessary measures to be adopted in the tourism industry in order to overcome the COVID-19 crisis

The qualitative exploratory research undertaken is based on the method of analysis of documents, official or statistical documents issued by various representative international organizations, namely UNWTO, European Commission, European Parliament, World Health Organization, Global Green Growth Institute. The secondary data used in our research, data provided by these organizations in the reports published during the pandemic will help us to highlight the changes generated by the COVID19 pandemic that must be faced by all those involved in tourism.

\section{Results and discussion}

\section{The current context in the global tourism sector}

In the last 10 years, tourism was one of the fastest growing economic sectors in the world, with forecasts confirming the continuous growth of this sector until the end of 2020. In 1950, there were 25 million tourists, with an annual increase of over 5.6\% until 2018, i.e., 1.4 billion people who made a trip abroad for tourism purposes. Thus, World Tourism Barometer (2016) shows that international arrivals will grow to 1.8 billion by 2030 (UNWTO, 2016, p. 14 quoted in Fayos-Solà and Cooper, 2019) (UNWTO, 2017). Forecasts showed a continuous increase, but due to the COVID-19 pandemic, the year 2020 completely changed the global situation of the economy in general, and tourism in particular (Mehta et al., 2021). Tourist destinations were affected by government policies on restrictions to limit the spread of the virus (Kunzmann, 2020). A decrease of up to -22.4 million tourists globally was recorded in the first quarter of 2020 (table no. 1).

Table no. 1. International Tourist Arrivals by (Sub)region (million)

\begin{tabular}{|c|c|c|c|c|c|}
\hline & $\mathbf{2 0 1 0}$ & $\mathbf{2 0 1 7}$ & $\mathbf{2 0 1 8}$ & $\mathbf{2 0 1 9}$ & $\mathbf{2 0 2 0}(\mathbf{Q 1 )}$ \\
\hline World & 952 & 1,333 & 1,408 & 1,462 & -22.4 \\
\hline Europe & 487 & 676.6 & 715.9 & 744.3 & -19.1 \\
\hline $\begin{array}{c}\text { Asia and the } \\
\text { Pacific }\end{array}$ & 208.2 & 324.1 & 347.7 & 360.6 & -34.6 \\
\hline Americas & 150.3 & 210.9 & 215.9 & 220.2 & -15.2 \\
\hline Africa & 50.4 & 63.3 & 68.8 & 73.2 & -12.5 \\
\hline Middle East & 56.1 & 57.7 & 60.1 & 64.2 & -10.8 \\
\hline
\end{tabular}

Source: UNWTO- World Tourism Barometer, 2020, p. 6 
Tourism Barometer, International tourism faces deepest crisis in history (UNWTO, 2020, p.14), shows that this is the largest decline in revenue recorded in the history of tourism with a high-risk for about 100 to 120 million direct jobs in tourism, especially in the economic destinations, where tourism generated labour, such as Small Island Developing States (SIDS), and, in general, in countries where the size of the tourism sector represented the largest share of total activities. In this context, the involvement of governments and international organisations is important to minimise the impact on jobs, companies, and livelihoods for millions of people. However, the perspectives are still extremely uncertain due to the evolution of the pandemic, which proves to be stronger than the previous ones, due to the intensity of international travel and the naivety of the population (Tsamakis et al., 2020). These factors led to severe measures, including travel restrictions which are still in place in many destinations, and stopping the virus is slow.

UNWTO (2020, p.10) called for the need to reopen tourism in a responsible, safe, coordinated, and hassle-free manner when travel restrictions are lifted. Restoring confidence in the sector is crucial. Thus, three scenarios for international tourism were outlined for 2020: Based on the three UNWTO scenarios published in May 2020, which showed decreases of the indicator of international tourist arrivals from $58 \%$ to $78 \%$, current trends suggest a decrease closer to $70 \%$ for 2020 (UNWTO, World Tourism Barometer, 18(5), August/September 2020). Later, alternative ways to recover from the global blockage were described, based on a possible lifting of travel restrictions in July, September, and December 2020.

Scenario 1 showed a recovery of the level recorded in 2019 in 2 and a half years, starting with the end of 2020 (until mid-2023). Scenario 2 suggested a recovery after 3 years (by the end of 2023), and scenario 3, the slowest, in 4 years (by the end of 2024) (UNWTO, World Tourism Barometer, 18(5), August/September 2020, p. 11). These recovery periods largely exceed the periods observed in previous crises, both globally (11 to 19 months) and for the most severely affected specific regions (1 to 3 and a half years). Looking into previous crises in World Tourism Barometer, 18(2), May (2020, p. 19), it took 11 months for international arrivals to regain pre-crisis levels after the 2003 SARS epidemic, 14 months after the attacks in September 11, 2001, and 19 months after the global economic crisis of 2009. In the most affected regions, the recovery took between 1-3 and a half years for tourist arrivals to reach pre-crisis levels. The analysis of previous crises showed that in recovery, the time varies greatly from one crisis to another, worldwide and by region.

Thus, it took 14 months for tourist arrivals in Asia, the United Kingdom and the Pacific to return to pre-crisis levels after the SARS epidemic. Europe regained its pre-global economic crisis levels after 29 months for international arrivals. The slowest but most affected region in the post-crisis recovery process was America after the terrorist attacks of September 11, 2001. It took up to 42 months (3 and a half years) for America to recover its international arrivals lost after this date. In this case, the longer recovery time was also due to the impact of the 2001 economic crisis in some American countries, as well as the SARS outbreak in early 2003, which affected Canada and other destinations.

Extended scenarios for 2021-2024 indicate a strong return in 2021 (UNWTO, World Tourism Barometer, 18(5), August/September 2020, p. 11). Even if these estimates turn out to be positive, international arrivals are expected to remain below 2019 levels in both 2021 and 2022 for all three scenarios, unless there is a major breakthrough in the treatment and prevention of COVID-19.

\section{The impact of COVID-19 on tourism and business environment in the tourism industry}

Since the beginning of the COVID-19 pandemic, tourists have faced situations of cancellation of travel plans, avoiding places and people they considered hazardous for health. The economic consequences of the COVID-19 pandemic, which began in late 2019 in Wuhan, China (Altuntas and Gok, 2021), have had serious effects on the global economic system, causing damage to the tourism sector. Thus, according to data provided by UNWTO (2020), after decades of global tourism growth, the forecasts for 2020 on international arrivals were revised. The crisis generated by COVID-19 came at a time when the tourism sector employed more people than ever before $(70$ million workers worldwide in the tourism sector) (Butnaru et al., 2020). In general, the problems caused by epidemics or pandemics have a strong impact on the tourism industry (the first area affected by such crises). In this context, economic agents engaged in tourism-related activities (travel agencies, hotels, restaurants, carriers, rent-à-car) 
recorded significant decreases in revenue due to lower demand, increased cancellations or indefinite postponements of services already contracted, etc. (Păvăluc, et al., 2020).

Harvard Business School, emphasises through Quelch (2020) that communication is very important in this period, and the leaders of the economic and social environment should build communication strategies. The pandemic period is a time when all resources must be used, and individuals should be encouraged to work online and to be mobilised effectively in crisis situations. The reunification of work teams has a potential role in overcoming uncertainties and the crisis itself. Currently, the society is in a new era of work - remote work - in which employees strive to assimilate the new rules, leaders do not yet have well-established work trajectories, and organisations must present a perspective on the future (Harvard Business School, Gerdeman, 2020). Carlisle, et al. (2021) also show that clear and decisive communication is the way by which leaders can support team members to work remotely in an uncertain and unprecedented time. Videoconferencing and data transmission by e-mail are the means by which the activity within an institution can be carried out predominantly in times of crisis (Harvard Business School, Gerdeman, 2020). The huge challenge of working from home is represented by the focus on work tasks, and the necessity to balance the family members' demands. Thus, flexibility, determined by time and availability, is important. Leaders have the task of assessing the contribution of each team member based on workload and work management capacity in the circumstances generated by the COVID-19 pandemic, then they have the role of balancing the tasks of a project according to emerging needs. There is a risk that, during this period, the individual's performance and commitment is affected, due to the fundamental changes caused by the crisis, but a proof of goodwill from organisations is expected (Harvard Business School, Gerdeman, 2020).

The outbreak of the COVID-19 pandemic affected the activity and development of tourism businesses, of hospitality industry (Altuntas and Gok, 2021, p. 2). In order to return to normal operating activities, the companies involved will have to comply with certain operating rules in this new environment. On April 15 $5^{\text {th }}, 2020$, the European Commission, in cooperation with the President of the European Council, presented the European Union's Guidelines to health protocols in tourist accommodation units. This part of the guidelines proposes the following principles for the operation of tourist accommodation structures (European Commission, 2020):

a) Health and safety of guests - guests using the tourist accommodation unit and workers participating in the provision of the tourist service must take measures to prevent infection and transmission of the SARS CoV-2 virus (Jones and Comfort, 2020, p. 3045) and of any other viruses. Measures must be clearly communicated, including through digital, visible and effective means, for both guests and employees.

b) Training of employees and tourists - all employees working in tourist units should be aware of the symptoms of COVID-19 and should be informed about the basic measures of infection prevention and control. Guests should also receive all necessary information in an accessible manner, including by digital means, before arrival and at the accommodation site, regarding all current guidance from local public health authorities, as well as specific measures which are implemented and which are affecting their arrival, stay and departure.

c) Personnel management - it is necessary to take into account measures to reduce the staff's presence in the unit, such as working from home for all personnel performing tasks which may be compatible with telework. Measures to reduce the number of physical contacts and the time of physical contact among the people in the unit should be considered.

d) Physical distancing and hygiene - the unit should implement specific measures to ensure that physical distancing is maintained in common areas where guests can gather for extended periods of time (i.e., more than 15 minutes), such as the establishment of a maximum number of guests allowed in each common area (i.e., restaurants, cafes, bars, lobby). The allocation of places or the (digital) provision of booking the places for meals or for swimming pools or gyms should be considered.

However, one of the advantages of tourism is that it is considered an activity in which tourists are mostly outdoors. In fact, tourists visiting tourist destinations are looking for a unique opportunity to relax in a clean and quiet environment. The lockdown led to a visible improvement in air quality and to a reduction in pollution by up to $30 \%$ in the areas most affected by COVID-19 (Girdhar, et al., 2021). 
Zawadka (2019) considers that rural tourism, through various types of physical activities, such as horseback riding, cycling and hiking, could increase in an environment dominated by the COVID-19 pandemic, with gyms closed and less time spent outdoors by the population.

The evolution of the COVID-19 pandemic left its mark on global crisis management, with 2020 being a devastating year for global health. Therefore, in 2021, countries around the world will have to continue the fight against COVID-19, with the awareness and hope that science is evolving, providing the availability to build strong health systems to maintain the health of the population. The World Health Organisation (2020) will do this during 2021 through: global solidarity for global health security, accelerating access to COVID-19 tests, medicines and vaccines, promoting everyone's health and addressing global health inequities, global leadership for science and data management, revitalising efforts to fight infectious diseases, controlling drug resistance, preventing and treating of noncommunicable diseases (NCDs - Noncommunicable diseases according to World Health Organization), and improving conditions for patients with mental health problems, rebuilding a better, greener and healthier world, the need to demonstrate greater solidarity - among nations, institutions, communities, and individuals, in the fight against the virus (WHO, 2020).

\section{Measures on reconfiguration of business environment in tourism industry during COVID-19 crisis}

\section{Rate of improvement of travellers' confidence}

Travellers' main concern in this period dominated by COVID-19 is to spend time safely. Thus, the first lever used by global organisations is to increase travellers' confidence.

Free movement of citizens without restrictions and the reopening of internal borders are necessary conditions for improving travellers' confidence, and basic conditions in global tourism. The COVID19 pandemic led all states to implement travel restrictions by forcing cross-border travellers to comply with quarantine. Business, study, or leisure travels were virtually impossible (Goniewicz, et al. 2020), but they had positive effects on the citizens' quality of life, by the awareness of the importance given to personal hygiene, maintaining of a safe distance in tourist destinations, and the authenticity of local communities (Koh, 2020).

Restoring safe transport is another important factor in increasing travellers' confidence. Thus, the European Commission, through Communication from the commission Covid-19: Guidelines on the progressive restoration of transport services and connectivity defined the ways in which the health of workers and of passengers in the transport sector can also be protected in relation to other economic activities, such as tourism. The European Agency for Health and Safety at the Workplace published general measures for health and safety at the workplace regarding the return to work (European Agency for Safety and Health at Work, 2020).

Tourist services with minimised hygiene risks are another important factor for increasing travellers' confidence. In addition, the European Commission, through COVID-19: EU Guidance for the progressive resumption of tourism services and for health protocols in hospitality establishments, established principles to guide the Member States when resuming tourism activities, and developed protocols related to COVID-19 for tourist accommodation structures, which will minimise the risks of infection for both customers and hotel personnel.

Digital technology started to be used naturally to provide transparent information to citizens who have the right to protect themselves and the others through responsible behaviour. Travellers need access to information in order to plan their trips, also during their actual holidays, about borders, travels, and tourist accommodation units, safety, and hygiene conditions of the place where they intend to travel, regarding the public health and safety regulations in force. Digital technologies and data are also important tools in the fight against the pandemic. For instance, the South Korean model was the most effective during the pandemic, helping to prevent lockdown by combining digital technology with other preventive strategies (Lee, et al., 2020). Consequently, the contact tracking strategies are strengthened, supporting public health authorities in monitoring and limiting the spread of the virus. The evolution from an Industry 4.0 to a Society 5.0 in the context of the COVID-19 pandemic involves the use of technological strategies including artificial intelligence and robotics (Sarfraz et al., 2021, p. 591). They contribute to the monitoring of social distancing (Gupta, et al., 2021), or to the facilitation of 
disinfection, especially in places with regular tourist flows. Digital innovation centres support the tourism sector in the new reality generated by the pandemic by providing robots for disinfection and cleaning, robots for crowd management, intelligent booking systems, etc. Consumers, coming in contact with human resources and robots, showed a positive attitude for structures equipped with robots, to the detriment of human interaction (Kim et al., 2021). The year 2021 will bring to everyone's attention a "hackathon" dedicated to the use of digital technologies in tourism (European Commission, Digital Innovation Hubs (DIHs) in Europa, 2021, Kwok and Koh, 2020).

Protecting people's rights to purchase tourist services through access to safe information, effective assistance and dispute resolution bodies contribute to the increase of travellers' confidence. The cases in which tourists are not always reimbursed directly the money paid in advance for transport and travel services cancelled due to the COVID-19 pandemic, often being sanctioned for cancelling tourist services, are examples to avoid in the next period (European Commission, Rețeaua Centrelor Europene ale Consumatorilor (ECC-Net) referitoare la COVID-19).

\section{Travel restrictions}

The gradual elimination of travel restrictions is coordinated globally, so that everyone can benefit from the holidays they desire in the period to come. By establishing this framework, the communication of the removal or maintenance of travel restrictions also aims to support the sustainability of the tourism ecosystem for future generations. Previous trends used for a return to normalcy promoted by new information technologies and communication in times of crisis, the common economy, local production and consumption, online learning, outdoor hiking or cycling, cooperation among regions will not be interrupted by travel restrictions (Kunzmann, 2020, p. 22). It is about supporting the Member States to lift isolation measures and to resume work and social life, in line with epidemiological and public health criteria. From the common European Roadmap to lifting the measures of limiting the spread of COVID19, elaborated by the European Commission (2020, p. 1), a coordinated framework based on common, objective and non-discriminatory principles, criteria and recommendations was established to guide Member States, competent authorities, industry bodies, economic operators and citizens through stages of the isolation ending process. However, lifting measures too quickly could cause a sudden resurgence of infections. Until the discovery of an effective vaccine or treatment, the needs and benefits of travel and tourism should be weighed against the risks of facilitating again the spread of the virus, and a recurrence of COVID-19 cases, which could require a reintroduction of isolation measures. For this reason, preparation plans need to be put in place at all levels - from global, national to individual units, transport operators, and other segments of the tourism sector - so that appropriate action can be taken quickly and in a coordinated manner, based on explicit criteria (Sigala, 2020, Altuntas and Gok, 2021). The needs and benefits of travel and tourism must be weighed against the risk of facilitating the resurgence of the virus and recurrent cases, which may require the reintroduction of isolation measures (Jamal and Budke, 2020).

\section{Predominant economic conditions}

While the COVID-19 pandemic initially began as a public health crisis, later it spread through the unprecedented blockade of the global economy and is still developing, with rapid effects, such as the collapse of the tourism sector. It depends on international travel restrictions, which are unlikely to be lifted soon, even if countries relaunch their domestic economies. The effects will be felt in many other sectors. As we learned from other crises, people from disadvantaged social and economic groups in developing countries are the most vulnerable, and probably the most affected (Perry, Aronson and Pescosolido, 2021), as they have low immunity, and their governments have no safety resources and cannot afford the kind of incentive packages which European countries and the USA implemented. The overriding priority is to get the economy back on track, favouring the development of digital industries which supported in this period online dating, remote work, culture and entertainment, education and research with software and intensive communication (Kunzmann, 2020), but the climate generated by the crisis has not disappeared. While we enjoy cleaner air than in recent decades in many cities, the resumption of the economy will bring back the same problems. The transition to green as a stimulus and development assistance packages are proposed to revive the economy and to address some of the worst consequences of the economic crisis (Global Green Growth Institute, 2020). 
The tourism industry is a sector in which offline and online information and service providers such as travel offices, digital platforms, tourist technology providers, travel agencies and operators, accommodation service providers, destination management organisations, attraction and recreation activities for travellers. Multinational companies and small enterprises operate in this sector, of which $90 \%$ are represented by SMEs (Dube, Nhamo and Chikodzi, 2020). Tourism exists in different types of regions: urban centres, islands, coastal, rural, remote and ultra-peripheral areas, being the backbone of the economies of many states, in terms of international arrivals and revenues.

The crisis we are facing had a strong impact globally, and especially in tourism, manifested by an acute liquidity crisis and the threat of jobs (Perry, Aronson and Pescosolido, 2021). This crisis has a major impact on small and medium-sized enterprises (Kunzmann, 2020), in the absence of liquidity and uncertainty, small and medium-sized enterprises are struggling to maintain their livelihoods, to obtain financing, and to keep their employees. Without immediate action and emergency funding, many companies could go bankrupt in the coming weeks or months (Donthu and Gustafsson, 2020). Carlisle, et al. (2021) presents studies providing guidelines and managerial strategies for operators, for future prosperity, as the COVID-19 pandemic continues to evolve. They include digital, social and ecological skills, understanding diversity, continuous development and communication skills.

During this period, global tourism will have as a short-term priority the promotion of local tourism. Quarantine measures and creativity in this crisis offer tourists the opportunity to enjoy the rich cultural diversity, the nature of their own country, the pleasure of discovering new experiences throughout the year close to home, and to taste the local products. These experiences can help increase the benefits of local economies, as stated by Williamson and Hassanli (2020). In particular, the negative scenarios referr to urban destinations with foreign visitors, while rural destinations (Kunzmann, 2020) have benefited due to local historical, natural, gastronomic and cultural attractions (Vaishar and Št’astná, 2020).

Cooperation between tourism actors is another important factor which leaves its mark in the general framework of tourism development locally, regionally, nationally, at EU level, and especially in the context of COVID-19 pandemic at global level (Jones and Comfort, 2020). However, for an efficient operation, a real cooperation is necessary between policy makers and groups of tourism-relevant actors.

\section{Conclusions}

The COVID-19 crisis illustrated the economic importance of tourism, but also its fragility, exposing the need for wiser growth and deeper connections to be developed between visitors and hosts, connected by a responsible industry and supporting resilient destinations.

The COVID-19 pandemic strongly influenced people's lives, the way they spend their leisure time, and the way they travel. Moreover, the pandemic raised significant challenges for business performance and development. The companies in the field of tourism have a great impact on the development of tourist areas, through their socio-economic contribution. Therefore, the outbreak of the COVID-19 pandemic affected the activity and development of businesses in the tourism sector, making it very important for decision makers to find ways to support these businesses, and for business owners to find ways to adapt to the context generated by the new business environment.

\section{References}

Altuntas, F. and Gok, M. S., 2021. The effect of COVID-19 pandemic on domestic tourism: A DEMATEL method analysis on quarantine decisions. International journal of hospitality management, 92, Article number: 102719.

Butnaru, G.I., Brînză, G. and Anichiti, A., 2020. The effects of the COVID-19 pandemic on businesses in the agro-tourism sector. Romanian Rural Tourism in International Context. Present and Prospects, Volume XLVI, Editors Georgia-Daniela Tacu-Hârșan, Alina-Petronela Haller, Dănuț Ungureanu, Ed.Performantica, Iași. [online] Available at: <https://8838d4ed-8442-4a58-9e20e8b43c5a8621.filesusr.com/ugd/ce8222_56efca6ca6544196a8fa9c7b1ed3844c.pdf $>$ [Accessed 05 February 2021]. 
Carlisle, S., Zaki, K., Ahmed, M., Dixey, L. and McLoughlin, E., 2021. The Imperative to Address Sustai-nability Skills Gaps in Tourism in Wales. Sustainability, 13(3), Article number: 1161.

Dannenberg, P., Fuchs, M., Riedler, T. and Wiedemann, C., 2020. Digital Transition by COVID-19 Pandemic? The German Food Online Retail. Tijdschrift voor economische en sociale geografie, 111(3), pp.543-560.

Do, B., Nguyen, N., D'Souza, C., Bui, H.D. and Nguyen, T. N. H., 2021. Strategic responses to COVID19: The case of tour operators in Vietnam. Tourism and Hospitality Research, 13, Article number: 1467358421993902.

Donthu, N. and Gustafsson, A., 2020. Effects of COVID-19 on business and research. Journal of Business Research, 117, pp.284-289.

Dube, K., Nhamo, G. and Chikodzi, D., 2021. COVID-19 cripples global restaurant and hospitality industry. Current Issues in Tourism, pp.1-4.

European Agency for Safety and Health at Work, 2020. COVID-19: BACK TO THE WORKPLACE Adapting workplaces and protecting workers, [online] Available at: $<$ https://osha.europa.eu/en/publications/covid-19-back-workplace-adapting-workplaces-andprotecting-workers/view $>$ [Accessed 01 February 2021].

European Commission (EU), 2020. Communication from the Commission Covid-19: Guidelines on the progressive restoration of transport services and connectivity. [pdf] Available at: $<$ https:/ec.europa.eu/transparency/regdoc/rep/3/2020/EN/C-2020-3139-F1-EN-MAIN-PART1.PDF $>$ [Accessed 25 January 2021].

European Commission (EU), 2020. COVID-19: EU Guidance for the progressive resumption of tourism services and for health protocols in hospitality establishments. [pdf] Available at: $<$ https://ec.europa.eu/info/sites/info/files/communication_tourismservices_healthprotocols.pdf $>$ [Accessed 25 January 2021].

European Commission, 2020. Communication from the commission to the European Parliament, The Council, The European Economic and Social Committee and the Committee of the Regions Tourism and Transport in 2020 and beyond. [pdf] Available at: $<$ https://ec.europa.eu/info/sites/info/files/communication-commission-tourism-transport-2020and-beyond_ro.pdf $>$ [Accessed 01 February 2021].

European Commission, 2020. Foaia de parcurs europeană comună către ridicarea măsurilor de limitare a răspândirii COVID-19. [pdf] Available at: $<$ https://cncpic.mai.gov.ro/sites/default/files/2020-

04/joint_eu_roadmap_lifting_covid19_containment_measures_ro.pdf $>$ [Accessed 01 February 2021].

European Commission, 2020. Rețeaua Centrelor Europene ale Consumatorilor (ECC-Net) referitoare la COVID-19, [online] Available at: < https://ec.europa.eu/info/live-work-travel-eu/consumerrights-and-complaints/resolve-your-consumer-complaint/european-consumer-centres-networkecc-net_ro $>$ [Accessed 08 January 2021].

European Commission, 2021. Digital Innovation Hubs (DIHs) in Europa, [online] Available at: $<$ https://ec.europa.eu/digital-single-market/en/digital-innovation-hubs-dihs-europe $>$ [Accessed 01 February 2021].

European Parliament, 2020. Covid-19's economic impact: $€ 100$ billion to keep people in jobs, [online] Available <https://www.europarl.europa.eu/news/en/headlines/society/20200416STO77205/covid-19-seconomic-impact-EU100-billion-to-keep-people-in-jobs.> [Accessed 01 February 2021].

Fayos-Solà, E. and Cooper, C., 2019. The Future of Tourism Innovation and Sustainability. Hoboken: Springer International Publishing AG. 
Girdhar, A., Kapur, H., Kumar, V., Kaur, M., Singh, D. and Damasevicius, R., 2021. Effect of COVID19 outbreak on urban health and environment. Air Quality Atmosphere and Health, 14(3), pp. 389397.

Global Green Growth Institute (GGGI), 2020. Strategy 2030 - 5 year Roadmap 2021-2025 for MPSC 0618. [pdf] Available at: <https://gggi.org/site/assets/uploads/2020/05/GGGI-Strategy-2030-5Year-Roadmap-2021-2025_for-MPSC_0618.pdf > [Accessed 02 February 2021].

Goniewicz, K., Khorram-Manesh, A., Hertelendy, A.J., Goniewicz, M., Naylor, K. and Burkle, F.M., 2020. Current response and management decisions of the European Union to the COVID-19 outbreak: a review. Sustainability, 12(9), Article number: 3838.

Gössling, S., Scott, D. and Hall, C.M., 2021. Pandemics, tourism and global change: a rapid assessment of COVID-19. Journal of Sustainable Tourism, 29, pp.1-20.

Gupta, A., Singh, A., Bharadwaj, D., and Mondal, A. K., 2021. Humans and Robots: A Mutually Inclusive Relationship in a Contagious World. International Journal of Automation and Computing, 18(2), pp.185-203.

Hafner, C.M., 2020. The spread of the Covid-19 pandemic in time and space. International Journal of Environmental Research and Public Health, 17, Article number: 3827.

Harvard Business School, Gerdeman, D. 2020. The New Rules for Remote Work: Pandemic Edition, [online] Available at: <https://hbswk.hbs.edu/item/the-new-rules-for-remote-work-pandemicedition?cid=spmailing-32094744-WK\%20Newsletter\%2004-01-2020\%20\%20Standard\%20(1)\%20C-April\%2001,\%202020> [Accessed 08 March 2021].

Harvard Business School and Quelch, J.A., 2020. 7 Leadership Principles for Managing in the Time of Coronavirus, [online] Available at: <https:/hbswk.hbs.edu/item/7-leadership-principles-formanaging-in-the-time-of-coronavirus $>$ [Accessed 08 March 2021].

Jamal, T. and Budke, C., 2020. Tourism in a world with pandemics: local-global responsibility and action. Journal of Tourism Futures, 6(2), pp. 181-188.

Jones, P. and Comfort, D., 2021. The COVID-19 crisis and sustainability in the hospitality industry. International Journal of Contemporary Hospitality Management, 32(10), pp.3037-3050.

Kim, S., Kim, J., Badu-Baiden, F., Giroux, M. and Choi, Y., 2021. Preference for robot service or human service in hotels? Impacts of the COVID-19 pandemic. International Journal of Hospitality Management, 93, Article number: 102795.

Koh, E., 2020. The end of over-tourism? Opportunities in a post-Covid-19 world. International Journal of Tourism Cities, 6(4), pp.1015-1023.

Kunzmann, K. R., 2020. Smart Cities After Covid-19: Ten Narratives. disP - The Planning Review, 56(2), pp.20-31.

Kwok, A.O.J. and Koh, S.G.M., 2020. COVID-19 and Extended Reality (XR). Current Issues in Tourism, pp.1-6, doi:10.1080/13683500.2020.1798896

Lee, D., Heo, K. and Seo, Y., 2020. COVID-19 in South Korea: Lessons for developing countries. World Development [e-journal] 135(1-2), Article number: 105057.

Liu, P.P., Blet, A., Smyth, D., and Li, H., 2020. The Science Underlying COVID-19. Circulation, 142(1), pp. 68-78.

Mehta, M. P., Kumar, G., and Ramkumar, M., 2021. Customer expectations in the hotel industry during the COVID-19 pandemic: a global perspective using sentiment analysis [Article; Early Access]. Tourism Recreation Research, pp.1-18. https://doi.org/10.1080/02508281.2021.1894692.

Păvăluc (Melinte), C., Brînză, G., Anichiti, A., Butnaru, G.I., 2020. COVID-19 pandemic and its effects on the tourism [pdf] Available <https://ceswp.uaic.ro/articles/CESWP2020_XII2_PAV.pdf $>$ [Accessed 08 March 2021]. 
Perry, B. L., Aronson, B., and Pescosolido, B. A., 2021. Pandemic precarity: COVID-19 is exposing and exacerbating inequalities in the American heartland. Proceedings of the National Academy of Sciences, 118(8), Article number: e2020685118.

Sarfraz, Z., Sarfraz, A., Iftikar, H. M. and Akhund, R., 2021. Is COVID-19 pushing us to the Fifth Industrial Revolution (Society 5.0)? Pakistan Journal of Medical Sciences, 37(2), pp.591-594.

Sigala, M., 2020. Tourism and COVID-19: Impacts and implications for advancing and resetting industry and research. Journal of Business Research, 117, pp.312-321.

The Guardian, 2020. The end of tourism? [online] Available at: $<$ https://www.theguardian.com/travel/2020/jun/18/end-of-tourism-coronavirus-pandemic-travelindustry> [Accessed 31 March 2021].

Tsamakis, K., Rizos, E., Manolis, A., Chaidou, S., Kympouropoulos, S., Spartalis, E., Spandidos, D., Tsiptsios, D. and Triantafyllis, A., 2020. [Comment] COVID-19 pandemic and its impact on mental health of healthcare professionals. Experimental and Therapeutic Medicine, 9, pp.3451-3453.

Vaishar, A., and Št'astná, M., 2020. Impact of the COVID-19 pandemic on rural tourism in Czechia Preliminary considerations. Current Issues in Tourism, pp.1-5. https://doi.org/10.1080/13683500.2020.1839027.

Williamson, J., and Hassanli, N., 2020. It's all in the recipe: How to increase domestic leisure tourists' experiential loyalty to local food. Tourism Management Perspectives, 36, Article number: 100745.

World Health Organization (WHO), 2020. 10 global health issues to track in 2021, [online] Available at: $\quad<$ https://www.who.int/news-room/spotlight/10-global-health-issues-to-track-in-2021> [Accessed 02 February 2021].

World Tourism Organization (UNWTO), 2017. Tourism key to development, prosperity and wellbeing, Tourism Towards 2030: Actual trend and forecast 1950-2030, [e-journal] Tourism Highlights 2017 Edition, p. 14. https://www.e-unwto.org/doi/pdf/10.18111/9789284419029

World Tourism Organization (UNWTO), 2020. Impact assessment of the COVID-19 outbreak on international tourism, [online] Available at: $<$ https://www.unwto.org/impact-assessment-of-thecovid-19-outbreak-on-international-tourism $>$ [Accessed 01 February 2021].

World Tourism Organization (UNWTO), 2020. World Tourism Barometer Volume 18, Issue 5, August/September 2020, International tourism down 65\% in first half of 2020. [pdf] Available at: $<$ https://www.e-unwto.org/doi/epdf/10.18111/wtobarometereng.2020.18.1.5> [Accessed 08 January 2021].

World Tourism Organization (UNWTO), 2020. Statement Mr. Zurab Pololikashvili. [pdf] Available at: $\quad<$ https://webunwto.s3.eu-west-1.amazonaws.com/s3fs-public/2020-12/201223-sg-statementen.pdf $>$ [Accessed 08 January 2021].

World Tourism Organization (UNWTO), 2020. World Tourism Barometer Volume 18, Issue 2, International tourism faces deepest crisis in history. [pdf] Available at: $<\mathrm{https} / / /$ webunwto.s3.eu-west1.amazonaws.com/s3fs-public/2020-05/UNWTO_Barom20_02_May.pdf> [Accessed 08 January 2021].

Zawadka, J. 2019. Agritourism As A Way Of Spending Free Time Of Urban Families With Children, Roczniki (Annals), Polish Association of Agricultural Economists and Agribusiness - StowarzyszenieEkonomistow Rolnictwa e Agrobiznesu (SERiA), p.3. 